\title{
Teachers' Perspective on E-Learning Readiness in Junior High School: A Case Study in Indonesia
}

\author{
Ade Irfan $^{1^{*}}$, Alfurqan ${ }^{2}$, Esty Saraswati N.H ${ }^{3}$, Safriana $^{4}$ \\ ${ }^{1,2}$ Faculty of Education and Teacher Training, Universitas Abulyatama, Aceh, Indonesia \\ ${ }^{3}$ Mathematics Education Department, STKIP PGRI Jombang, Jawa Timur, Indonesia \\ ${ }^{4}$ Faculty of Education and Teacher Training, Universitas Malikussaleh, Aceh, Indonesia \\ *Corresponding Author: Ade Irfan, adeirfan_matematika@abulyatama.ac.id
}

\begin{abstract}
This paper aimed to reveal the readiness of Junior High Schools in Banda Aceh and Jombang to implement e-learning based on the teacher's perspective through six factors of e-learning readiness, including student readiness factors, teacher readiness, infrastructure readiness, school culture readiness, and face-to-face learning tendencies. Data was collected through an online questionnaire, involving 69 students from various junior high schools. The findings of this study showed that the readiness for implementing e-learning in Junior High Schools in Banda Aceh and Jombang was at a score of 3.5 and was in the ready category but still needed improvement. Six factors were the basis for determining the readiness to implement e-learning, four of which were in the ready category but required a slight improvement of student readiness factor, teacher readiness factor, school culture readiness, and management readiness. While, the other two factors were in the unready category including the infrastructure readiness factor and readiness for face-to-face learning tendencies.
\end{abstract}

Keywords: e-learning, readiness, teachers' perspective, junior high school

\section{Introduction}

The COVID-19 pandemic has forced the government to close educational institutions and schools to prevent the broader spread of COVID-19. The closure of various educational institutions causes changes in the habits of teachers, students, and schools in carrying out the learning process. The shift in habits and culture in implementing teaching and learning activities would undoubtedly profoundly impact schools, teachers, and students (Mailizar et al., 2020).

The learning process carried out in the classroom face-to-face is replaced with online learning. Teachers and students must use various electronic communication media that were previously usually used in communication into learning media. The learning process using electronic communication technology both conventionally and remotely is then called electronic learning or e-learning (Al-araibi et al., 2019; Mustika \& Sapriya, 2019).

E-learning is a new learning medium for schools, even though some universities have implemented it (Ramadan et al., 2019). Many studies revealed the applications of elearning in learning for college students (Al-araibi et al., 2019; Ayasrah, 2020; Hariyanti et al., 2017; Kilani \& Awad, 2019; Mardhiyana \& Nasution, 2018; Neupane et al., 2020; Rohayani et al., 2015; Setiaji \& Dinata, 2020; Unal \& Soydal, 2014). Likewise, research on the analysis of the level of e-learning readiness also focuses on students (Kalkan, 2020; Yusuf et al., 2020).

Research on readiness and evaluation of the implementation of e-learning in schools is still very minimal and rarely done (Jamal, 2020). Thus it is very natural if schools have 
limitations and do not have experience with e-learning, and schools do not prepare elearning resources and experience difficulties, especially when teachers do not understand the use of online applications (Zaharah \& Kirilova, 2020).

The lack of access to information and research on the application of e-learning in schools has resulted in various problems in the application of e-learning. Finally, a student in Bone city ended his life due to depression due to an online study assignment (Kompas.com, 2020). Therefore, it is necessary to conduct an in-depth study of the readiness to implement e-learning in schools so that the incident does not happen again. In addition, knowing the readiness of schools in implementing e-learning is much more important than evaluating the implementation of e-learning.

The purpose of this study was to reveal and describe the readiness to implement elearning in junior high schools based on teacher perceptions. To achieve the aim, the study aspired to answer the question: how was the readiness to implement e-learning in junior high schools in Banda Aceh and Jombang cities?

\section{Method}

This research was a survey research with descriptive-quantitative research type. Descriptive research is intended to describe the characteristics and facts systematically and accurately from the population and the observed field (Dunlock, 1993). At the same time, quantitative is considered capable of providing responsible, valid, objective, and generalizable findings (Fraenkel et al., 2011).

Proportional random sampling or Stratified Random Sampling was used in this study to obtain the representative participants. The number of participants in this study was 69 with various subject teachers in junior high schools. Moreover, the majority of participants had undergraduate degrees $(89,1 \%)$, whilst the remaining had post-graduate degrees $(10,9 \%)$. Most of the participants had under 11 years of teaching experience $(53,6 \%)$, and most of them $(60,9 \%)$ had been certificated as professional teachers by the Indonesian Ministry of Education and Culture. Further details of participants' demographic information are presented in Table 1.

The questionnaire used in this study was based on the E-Learning Readiness Survey (ELRs) offered by So and Swatman (2006) with some modifications. The questionnaire consists of 6 parts: student readiness, teacher readiness, infrastructure readiness, management readiness, school culture readiness, and readiness for face-to-face learning tendencies. All responses on the teacher's level perceptive were coded on a 5-point scale. Descriptive statistical analysis was employed to answer the research question. Regarding that, analysis of research data that each e-learning readiness factor is carried out using the following formula:

$$
\bar{x}=\frac{x}{n}
$$

The average score of e-learning readiness obtained from the previous calculation will be assessed using the e-learning readiness assessment model offered by Aydin \& Tasci (Aydin \& Tasci, 2005), as shown in Figure 1.

Table 1. Demographic Background of Participants

\begin{tabular}{clccc}
\hline No & Demographic Background & Category & $\begin{array}{c}\text { Number of } \\
\text { Participant }\end{array}$ & Percentage \\
\hline 1 & Levels of Education & Undergraduate Degree & 63 & 91.3 \\
& & Post Graduate Degree & 6 & 8.7
\end{tabular}


2 Teaching Experience

3 Teacher Certification

$\begin{array}{ccc}\text { 0-5 Years } & 14 & 20.3 \\ \text { 6-10 Years } & 27 & 39.1 \\ \text { 11-15 Years } & 23 & 33.3 \\ \text { 16-20 Years } & 3 & 4.3 \\ \text { ore than 20 Years } & 2 & 2.9 \\ \text { Yes } & 42 & 60.9 \\ \text { No } & 27 & 39.1\end{array}$

The minimum average score that must be obtained for each factor to be declared ready for the implementation of e-learning was 3.41. The range of values and categories of e-learning readiness (ELR) are presented in Table 2.

Table 2. E-Learning Readiness Grades and Categories

\begin{tabular}{cl}
\hline ELR Grades & \multicolumn{1}{c}{ Categories } \\
\hline $1 \leq \bar{x} \leq 2,6$ & Not ready (need many improvements) \\
$2,6<\bar{x} \leq 3,4$ & Not ready (need a slight improvement) \\
$3,4<\bar{x} \leq 4,2$ & Ready (need a slight improvement) \\
$4,2<\bar{x} \leq 5$ & Ready (Implementation of e-learning can be continued) \\
\hline
\end{tabular}

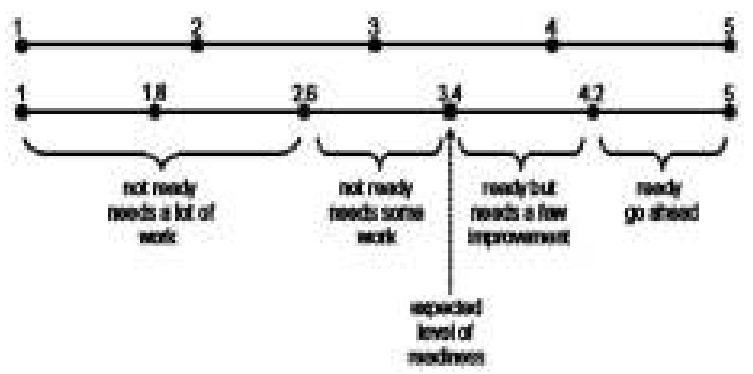

Figure 1. E-Learning Readiness Assessment Model According to Aydin \& Tasci

\section{Results and Discussions}

Based on the results, the average overall ERL score for junior high schools in Banda Aceh and Jombang was 3.5. The score indicates that the readiness to implement elearning in junior high schools was in the ready category (needs a slight improvement). The category scores on each factor of e-learning readiness were shown in Figure 2.

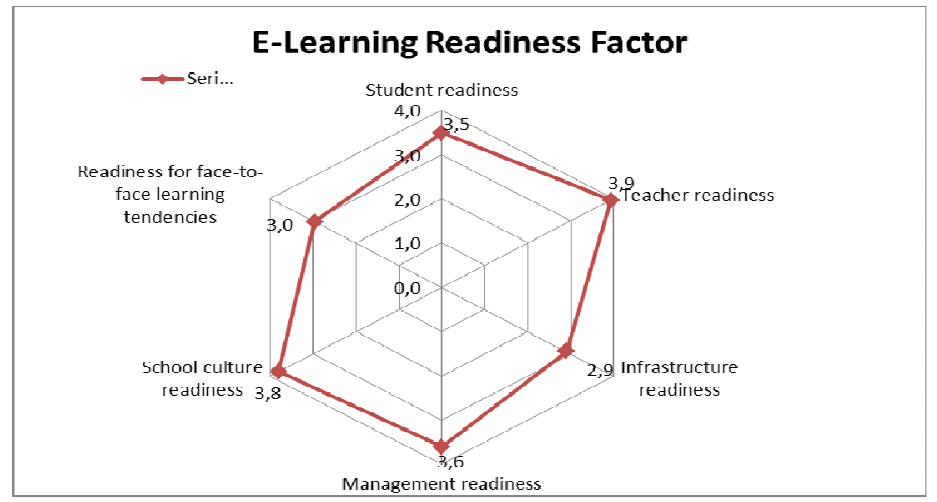

Figure 2. E-Learning Readiness Factor

\section{Student Readiness}

Based on the results, it was known that the average score of e-learning readiness for the readiness factor of students was 3.5. The detailed data regarding the readiness to 
implement e-learning on the readiness factor of students are presented in Table 3.

Table 3. ELR Scores on Student Readiness Factors

\begin{tabular}{|c|c|c|c|c|c|c|c|c|c|c|}
\hline Statement & P1 & P2 & P3 & P4 & P5 & P6 & P7 & P8 & P9 & P10 \\
\hline Statement Average & 3.7 & 3.4 & 3.4 & 3.0 & 3.5 & 4.0 & 3.6 & 3.6 & 3.5 & 3.3 \\
\hline Factor Average & \multicolumn{10}{|c|}{3.5} \\
\hline
\end{tabular}

Based on Table 3, it is known that the ELR scores for almost all statements on the readiness factor of students are still in the ready category but cannot be continued. In other words, the readiness for the implementation of e-learning in the readiness factor of students was ready but still requires improvement. Students' readiness in understanding e-learning was in the ready category, but the application of e-learning cannot be continued and required a slight increase in students' understanding of e-learning. The support of parents of students in implementing e-learning in schools has not yet reached the ready category and can be continued. Students' readiness in managing time in the use of e-learning was in the ready category but still cannot be continued and required improvement. The same thing happened to students' readiness in basic computer skills (typing, accessing the internet, editing, etc.), requiring a slight improvement. The willingness of students to use information technology such as e-learning or computers to complete daily tasks still needs improvement and cannot be continued even though they were in the ready category.

Although the average ELR score of students' readiness to work together in completing daily tasks using e-learning was 3.3, this statement was still not at the minimum average score that must be obtained to be declared ready to implement e-learning, which was 3.41. In other words, students were still not ready to work together in completing daily tasks using elearning. The readiness of students to follow the instructions on the computer screen to solve a problem was still in the unprepared category and requires improvement. That was known from the ELR score for the statement "My students can follow instructions on a computer screen to solve a problem" was 3.6. The same thing also happened to the readiness of students to access the internet. The ELR score on the statement "My students have no difficulty accessing the internet" was 3.5 , which was in the prepared category and requires improvement.

Finally, the teacher perceives that the participants were not ready to use e-learning and need improvement. That was known from the ELR score for the statement "my students are ready to use e-learning," which was only at an average score of 3.0.

There are many things that schools can do to improve students' understanding of elearning, including socialization and guidance on e-learning. The same thing can also be done in seeking support from the guardians of students in implementing e-learning in schools. On the other hand, schools also need to familiarize students with using computers and accessing the internet in learning so that students are accustomed to using the internet to improve their learning outcomes.

\section{Teacher Readiness}

Based on the results of research and research data processing, it is known that the average score of e-learning readiness for the teacher readiness factor was 3.9. The detailed data regarding the readiness to implement e-learning on the teacher readiness factor is presented in Table 4.

Table 4. ELR Scores on Teacher Readiness Factors

\begin{tabular}{lcccccccccc}
\hline Statement & P11 & P12 & P13 & P14 & P15 & P16 & P17 & P18 & P19 & P20 \\
\hline Statement Average & 4.2 & 4.0 & 3.8 & 3.7 & 4.2 & 4.0 & 4.0 & 3.8 & 3.9 & 3.9 \\
Factors Average & & & \multicolumn{6}{c}{3.9} & & \\
\hline
\end{tabular}


Based on Table 3, it is known that the ELR scores for almost all statements on the teacher readiness factor were in the ready category but cannot be continued. In other words, the readiness for implementing e-learning on the teacher readiness factor was in the ready category but required improvement.

The average ELR score for the statement "I understand what e-learning is" was 4.2, which was in the ready category and only needs a slight improvement to continue implementing e-learning in schools. This situation shows that there was a good perception of their readiness to understand e-learning.

The teacher's perception of e-learning that can help and improve the teaching and learning process was still in the ready category and cannot be continued. The same thing also happens to teachers' perception of implementing e-learning in schools that were currently still in the ready category and cannot be continued.

\section{Infrastructure Readiness}

Based on the research results, it is known that the average score of e-learning readiness for infrastructure factors was 2.9. The detailed data regarding the readiness to implement elearning on infrastructure factors are presented in Table 5.

Table 5 ELR Scores on Infrastructure Readiness Factors

\begin{tabular}{lccccc}
\hline Statement & P21 & P22 & P23 & P24 & P25 \\
\hline Statement Average & 3.0 & 2.9 & 2.9 & 2.8 & 3.0 \\
Factor Average & & & 2.9 & & \\
\hline
\end{tabular}

The readiness of information technology infrastructure that supports e-learning in schools was in the not ready category and still needs a slight requires improvement with an average score of 2.9 .

The readiness of financing in implementing e-learning in schools also needs improvement and cannot be continued with an average score of 3.0. Server readiness in implementing and managing e-learning well in schools was still not ready and required improvement with an average score of 2.9. Meanwhile, internet access speed in schools was sufficient to access e-learning. It was still not ready and required a significant increase with an average score of 3.0 .

The infrastructure readiness factor was one of the important factors in the implementation of e-learning in schools. Apitep and Dolly Samson (Saekow, 2011) explained that to introduce e-learning in an organizational environment, one must have readiness in the technological aspect. So, it can be necessary to improve this infrastructure aspect to be able to implement e-learning in schools, the implementation will produce optimal results.

\section{Management Readiness}

Based on the results of research and research data processing, it is known that the average score of e-learning readiness for management factors was 3.6. The detailed data regarding the readiness to implement e-learning on management factors are presented in Table 6.

Table 6. ELR Scores on Management Readiness Factors

\begin{tabular}{lccc}
\hline Statement & P26 & P27 & P28 \\
\hline Statement Average & 4.2 & 3.6 & 3.0 \\
Factor Average & & 3.6 & \\
\hline 6
\end{tabular}

Based on Table 6 , it is known that the ELR scores for almost all statements on management factors were in the ready category but required improvement and cannot be continued. The readiness for the implementation of e-learning on the management factor was in the ready category and still required improvement. 
The readiness of the principal's knowledge and education staff regarding e-learning was in the ready category and only required a slight increase to continue with an average score of 4.2. The readiness of principals and education staff to support the implementation of e-learning in teacher-led subjects was in the ready category but cannot be continued and still required improvement with an average score of 3.6. Meanwhile, school readiness by having e-learning plans in the future was also still in the ready category and required improvement with an average score of 3.0 .

\section{School Culture Readiness}

Based on the study results, it was found that the average score of e-learning readiness for school culture factors was 3.8. The detailed data regarding the readiness to implement elearning on school cultural factors is presented in Table 7.

\begin{tabular}{lcccc}
\multicolumn{2}{c}{ Table 7. ELR Scores on School Culture Factors } \\
\hline Statement & P29 & P30 & P31 & P32 \\
\hline Statement Average & 4.2 & 3.4 & 4.2 & 3.6 \\
Factor Average & \multicolumn{4}{c}{3.8} \\
\hline
\end{tabular}

Based on Table 7, it is known that the ELR scores for almost all statements on school culture factors were in the ready category but only need a slight improvement and still cannot be continued where the readiness for the application of e-learning on all statements of school cultural factors was in the ready category and required improvement.

The readiness of colleagues in knowledge about e-learning was in the ready category and only required a slight increase to proceed with an average score of 4.2. Readiness to have the same goal in implementing e-learning was also in the ready category but cannot be continued and also still required a slight increase with an average score of 3.4.

Meanwhile, school readiness in cultivating mutual diversity and cooperation was still in the ready category and required improvement with an average score of 4.2. The same also applies to readiness in the IT capabilities of colleagues in implementing e-learning. Teachers have the perception that they are ready but cannot continue and needed improvement.

\section{Readiness for Face-to-Face Learning Tendencies}

Based on the results of research and research data processing, it is known that the average score of e-learning readiness for the face-to-face tendency factor was 3.0. The detailed data regarding the readiness to implement e-learning on the face-to-face learning tendency factor are presented in Table 8 .

Table 8. ELR Scores on Face-to-Face Learning Factors

\begin{tabular}{lcc}
\hline Statement & P33 & P34 \\
Statement Average & 2.9 & 3.1 \\
Factor Average & \multicolumn{2}{c}{3.0} \\
\hline
\end{tabular}

Based on Table 7, it is known that the ELR score for statements on the face-to-face learning tendency factor was in the unprepared category and required improvement where the readiness for the implementation of e-learning on all statements of the tendency factor was not ready and required improvement.

The teacher's readiness in choosing online learning over classroom learning was in the unprepared category and required improvement with an average score of 2.9. While the same thing also happened to students' readiness in choosing online learning over classroom learning, they were also in the unprepared category and needed an increase with an average score of 3.1 . 
Teachers assumed that both teachers and students tend to prefer face-to-face learning in class rather than online learning. Unpreparedness for this factor was influenced by previous readiness factors, including school infrastructure in the online application that was still not ready and teacher readiness that still needed improvement.

\section{Conclusions}

The readiness for implementing e-learning in Junior High Schools in Banda Aceh has an ELR score of 3.5 which was in the ready category but still needed improvement on all factors. Of the six factors that form the basis for determining the readiness to implement elearning in Junior High Schools in Banda Aceh based on the teacher's perspective, four factors are ready but required a slight improvement. The four factors were student readiness, teacher readiness, management readiness, and school culture. While the infrastructure readiness factor and face-to-face learning tendency factor, in this case, were still in the category of not being ready and needed an improvement.

\section{Acknowledgments}

We would like to express our high appreciation to the Directorate General of Higher Education, Research and Technology of the Ministry of Education, Culture, Research, and Technology, who has provided research grants through the Beginner Lecturer Research scheme by Decree No. 1867/E4/Ak.04/2021 with Agreement/Contract Number 074/E4.1/AK.04.PT/2021.

\section{References}

Al-araibi, A. A. M., Mahrin, M. N. bin, \& Yusoff, R. C. M. (2019). Technological aspect factors of E-learning readiness in higher education institutions: Delphi technique. Education and Information Technologies, 24(1), 567-590.

Ayasrah, F. T. M. (2020). Exploring E-Learning Readiness as Mediating between Trust, Hedonic Motivation, Students' Expectation, and Intention to Use Technology in Taibah University. Journal of Education \& Social Policy, 7(1), 101-109.

Dunlock, H. L. (1993). Research Design: Descriptive Research Definitions of. Journal of Pediatric Oncology Nursing, 10(4), 154-157.

Fraenkel, J. ., Wallen, N. E., \& Hyun, H. H. (2011). How To Design and Evaluate Research in Education. New York: McGraw-Hill.

Aydin, C., \& Tasci, D. (2005). Measuring Readiness for e-Learning: Reflections from an Emerging Country. 8(4), 244-257.

Hariyanti, E., Kartono, \& Purwanti, E. (2017). Pengukuran E-Learning Readiness Untuk Mendukung Keberhasilan Pengembangan E-Learning ( Studi Kasus: FstUniversitas Airlangga ). Jurnal Sistem Informasi, 5(3), 1-6.

Jamal, S. (2020). Analisis Kesiapan Pembelajaran E-Learning Saat Pandemi Covid-19 Di SMK Negeri 1 Tambelangan. Jurnal Nalar Pendidikan, 8(1), 16-22.

Kalkan, N. (2020). Investigation of e-learning readiness levels of university students studying in different departments. African Educational Research Journal, 8(3), 533539.

Kilani, Y., \& Awad, H. (2019). E-Learning Readiness of Jordanian Universities. Information and Knowledge Management, 7(11), 1-6.

Kompas.com. (2020). siswi SMA tewas usai tenggak racun diduga depresi akibat beban tugas daring. Kompas.Com. https://regional.kompas.com/read/2020/10/17/19301891/siswi-sma-tewas-usaitenggak-racun-diduga-depresi-akibat-beban-tugas-daring 
Mailizar, Almanthari, A., Maulina, S., \& Bruce, S. (2020). Secondary school mathematics teachers' views on e-learning implementation barriers during the COVID-19 pandemic: The case of Indonesia. Eurasia Journal of Mathematics, Science and Technology Education, 16(7), em1860.

Mardhiyana, D., \& Nasution, N. B. (2018). Kesiapan Mahasiswa Pendidikan Matematika Menggunakan E-Learning dalam Menghadapi Era Revolusi Industri 4.0. Seminar Nasional Pendidikan Matematika Ahmad Dahlan, 2018, 31-35.

Mustika, M., \& Sapriya. (2019). The readiness of social studies teacher in e-learning based: A survey through TPACK approach. ACM International Conference Proceeding Series, 32-35.

Neupane, H. C., Sharma, K., \& Joshi, A. (2020). Readiness for the Online Classes during COVID-19 Pandemic among Students of Chitwan Medical College. Journal of Nepal Health Research Council, 18(2), 316-319.

Ramadan, R., Pradnyana, I. M. A., \& Suyasa, P. W. A. (2019). Pengukuran Tingkat Kesiapan Implementasi E-Learning (E-Learning Readiness) Di SMA N 2 Singaraja Menggunakan Model Chapnick. Jurnal Pendidikan Teknologi Dan Kejuruan, 16(2), $258-266$.

Rohayani, A. H. H., Kurniabudi, \& Sharipuddin. (2015). A Literature Review: Readiness Factors to Measuring e-Learning Readiness in Higher Education. Procedia Computer Science, 59(January 2020), 230-234.

Saekow, A. (2011). E-learning Readiness of Thailand's Universities Comparing to the USA's Cases. International Journal of E-Education, e-Business, e-Management and e-Learning, 1(2), 216-131.

Setiaji, B., \& Dinata, P. A. C. (2020). Analisis kesiapan mahasiswa jurusan pendidikan fisika menggunakan e-learning dalam situasi pandemi Covid-19. Jurnal Inovasi Pendidikan IPA, 6(1), 59-70.

So, T., \& Swatman, P. M. C. (2006). e-Learning readiness of Hong Kong teachers. Hong Kong IT in Education Conference, February, 6-8. http://blog.uny.ac.id/nurhadi/files/2010/08/swatman-hongkong.pdf

Unal, Y., \& Soydal, I. (2014). Students Readiness for E-Learning: An Assesment on Hacettepe University Department of Information Management. Communications in Computer and Information Science, 1(January), 211-219.

Yusuf, F., Syamfithriani, T. S., \& Mirantika, N. (2020). Analisis Tingkat Kesiapan Pengguna E-Learning Universitas Kuningan Dengan Menggunakan Model Technology Readiness Index (TRI). Jurnal Nuansa Infromatika, 14(2), 39-50.

Zaharah, Z., \& Kirilova, G. I. (2020). Impact of Corona Virus Outbreak Towards Teaching and Learning Activities in Indonesia. SALAM: Jurnal Sosial dan Budaya Syar-i, 7(3), 269-282. 